\title{
Elimination of Viruses from Plant Tissue Cultures
}

\author{
Toshihiro OMURA* and Satoshi WAKIмоTo* \\ 大村敏博*・脇本 哲*：植物カルス組織からの各種ウイルスの除去
}

\begin{abstract}
Tobacco callus tissues infected with potato virus $\mathrm{X}$ (PVX), potato virus $\mathrm{Y}$ (PVY) or cucumber mosaic virus (CMV), tomato callus tissue infected with tobacco mosaic virus (TMV) or potato callus tissue infected with PVX were established respectively from the stems of inoculated plants. These tissues were successively transferred under the suitable conditions for proliferating either compact tissue or soft tissue, and the virus concentrations in the tissues were periodically assayed. In all the host-virus combinations tested, virus concentration in callus tissues rapidly decreased under the conditions of producing friable callus. Generally, the virus concentration was maintained at high level in compact callus. However, CMV in tobacco callus tissue and TMV in tomato callus tissue decreased rapidly even under the conditions to grow compact callus.
\end{abstract}

(Received March 23, 1978)

\section{Introduction}

Disappearance of tobacco mosaic virus (TMV) in tobacco callus tissue under certain conditions was reported by several workers ${ }^{1,2,3,4,6,12)}$. Svobodova ${ }^{13)}$ reported that virus-free plants were obtained from tobacco callus derived from potato virus $Y$ (PVY)-infected tobacco stem. Pillai and Hildebrandt ${ }^{11}$ ) also produced virus-free geranium plants from virus infected plants through tissue culture. These workers, however, did not refer the nature or cell arrangement of the tissue to the change of virus concentration in callus tissue. Kondo ${ }^{5)}$ made an attempt to maintain plant viruses by means of callus tissue. Carnation mottle virus, TMV, and cucumber mosaic virus (CMV) were successfully maintained in green colored calli and he briefly noted that carnation mottle virus was lost in the white callus.

In the previous paper $^{8)}$ we reported that disappearance of TMV in tobacco callus tissue closely related with compactness of the tissue and it rapidly disappeared by successive transfers of the translucent part of the callus tissue to the medium containing high concentration of NAA and low concentration of kinetin. In this experiment, the similar method was applied to eliminate several kinds of virus from infected plant tissue cultures.

\section{Materials and Methods}

Viruses. Potato virus $\mathrm{X}(\mathrm{PVX})$ and PVY kindly supplied by Dr. H. Tochihara, Institute for Plant Virus Research, Japan, and ordinary strains of both CMV and TMV preserved in our laboratory were used in this experiment.

* Faculty of Agriculture, Kyushu University, Fukuoka, 812, Japan 九州大学農学部 
Callus tissues. Five kinds of host-virus combinations, i. e., tobacco plant (Nicotianata tabacum cv. Bright Yellow) infected with PVX, PVY, or CMV, tomato plant (Lycoperisicon esculentum Mill cv. Best of all) infected with TMV and potato (Solanum tuberosum L. cv. May Queen) infected with PVX were used. Tobacco plant was inoculated with each virus when the largest leaf was about $12 \mathrm{~cm}$ in length. Tomato and potato plants were inoculated respectively with TMV and PVX when the plants were about $10 \mathrm{~cm}$ tall. At 10 days after inoculation of CMV and at 20 days after inoculation of TMV, PVX or PVY, the infected plants were used for callus establishment. A stem tissue obtained from a part 5-10 cm from the apex was surface sterilized with $70 \%$ ethanol for 3 min followed by the treatment with $2.5 \%$ sodium hypochlorite solution for $3 \mathrm{~min}$, washed with sterile distilled water and sectioned into $5 \mathrm{~mm}$ segments in a sterile petri dish. Each segment

Table 1. Cultural conditions adopted in this experiment

\begin{tabular}{c|c|c|l|l}
\hline \hline $\begin{array}{l}\text { Cultural } \\
\text { condition }\end{array}$ & $\begin{array}{l}\text { NAA } \\
\text { conc. } \\
\text { (mg/1) }\end{array}$ & $\begin{array}{l}\text { Kinetin } \\
\text { conc. } \\
\text { (mg/l) }\end{array}$ & $\begin{array}{l}\text { Light } \\
\text { intensity } \\
\text { (lux) }\end{array}$ & $\begin{array}{l}\text { Nature of } \\
\text { the tissue used } \\
\text { for transfer }\end{array}$ \\
\hline I & 10 & 0.002 & 3,000 & Translucent \\
II & 1 & 0.2 & 3,000 & Translucent \\
III & 1 & 0.2 & 3,000 & Green \\
IV & 1 & 2 & 12,000 & Green \\
\hline
\end{tabular}

was placed on the modified Murashige and Skoog ${ }^{7)}$ medium (stock medium) containing a few a mount of plant hormones as reported previously ${ }^{8)}$.

The preparations were grown at $25 \mathrm{C}$ under different conditions, as shown in Table 1 . The callus tissue became translucent under the conditions I and II,

while it became compact under the conditions III and IV.

Infectivity assay. Concentrations of PVX and PVY in callus tissues were assayed by means of inoculating the suspensions of macerated tissues to local lesion hosts, Gomphrena globosa and Chenopodium amaranticolor, respectively. The greenhouse grown plants in $12 \mathrm{~cm}$ pots were moved to $25 \mathrm{C}$ air conditioned greenhouse a week before inoculation. The upper and lower leaves of the plants were cut off leaving a few number of fully expanded leaves three days before inoculation. A small piece of callus tissue was weighed and homogenized with earthenware mortar and muller in $0.1 \mathrm{M}$ phosphate buffer, $\mathrm{pH} 7.0$, to make 10 times dilution $(\mathrm{W} / \mathrm{V})$. Inoculation was made by cotton swabs on half leaves of the plants as reported previously ${ }^{8}$.

The 10 times diluted inoculum prepared from the virus-infected stem was also inoculated to the opposite half leaves as a standard in each experiment. Local lesions on G. globosa leaves were counted at 5th day after inoculation and those on $C$. amaranticolor leaves at 14-18 days after inoculation.

Half leaf method by using cotyledon of Vigna sinensis L. cv. Kurodanesanzyaku was applied for assaying CMV concentration. In this case, the 10 times diluted (W/V) suspension prepared from freeze-dried CMV-infected $N$. glutinosa leaves was inoculated on the opposite half-leaves as a control, which usually produced about 50 local lesions on a half leaf of $V$. sinensis $L$. without significant decrease during the experiments. Eight leaves were inoculated with each specimen. Local lesions were counted 2 days after inoculation.

To assay TMV infectivity, half-leaf method with $N$. glutinosa was used as reported previously ${ }^{8)}$.

\section{Results}

\section{Change of PVX concentration in tobacco callus tissue}

Under the cultural condition I, tobacco calli became yellowish green and soft at the end of the first generation and rapidly proliferated into translucent and friable 
Table 2. Change of PVX concentration in tobacco callus tissue

\begin{tabular}{|c|c|c|c|c|c|c|c|}
\hline \multirow{2}{*}{$\begin{array}{l}\text { Cultural } \\
\text { condition }\end{array}$} & \multirow{2}{*}{$\begin{array}{l}\text { Exp. } \\
\text { no. }\end{array}$} & \multicolumn{6}{|c|}{ Generation $^{\text {a) }}$} \\
\hline & & 0 & 1 & 2 & 3 & 4 & 5 \\
\hline \multirow{3}{*}{ I } & 1 & $100^{b)}$ & 7 & 0 & 0 & 0 & 0 \\
\hline & 2 & 100 & 2 & 0 & 0 & 0 & 0 \\
\hline & 3 & 100 & 0 & 0 & 0 & 0 & 0 \\
\hline \multirow{3}{*}{ IV } & 1 & 100 & 131 & 146 & 144 & 227 & 158 \\
\hline & 2 & 100 & 128 & 137 & 143 & 135 & 157 \\
\hline & 3 & 100 & 112 & 133 & 8 & 0 & 0 \\
\hline
\end{tabular}

a) Transferred every 30 days.

b) Relative concentration of PVX as compared to that in the stem of PVX-infected tobacco. Ten fold (W/ V) diluted suspension of the stem produced about 80 local lesions on a half leaf of G. globosa.

Table 3. Change of PVY concentration in tobacco callus tissue

\begin{tabular}{c|c|c|r|r|r|r|c}
\hline \hline \multirow{2}{*}{$\begin{array}{c}\text { Cultural } \\
\text { condition }\end{array}$} & \multirow{2}{*}{$\begin{array}{c}\text { Exp. } \\
\text { no. }\end{array}$} & \multicolumn{6}{|c}{ Generation $^{\text {a) }}$} \\
\cline { 3 - 8 } & 1 & $100^{\mathrm{b})}$ & 6 & - & 0 & 0 & 0 \\
\hline \multirow{3}{*}{ I } & 2 & 100 & 16 & - & 0 & 0 & 0 \\
& 3 & 100 & 6 & - & 0 & 0 & 0 \\
\hline \multirow{3}{*}{ IV } & 1 & 100 & 386 & 83 & 158 & 169 & 243 \\
& 2 & 100 & 154 & 164 & 129 & 152 & 142 \\
& 3 & 100 & 172 & 154 & 143 & 151 & 142 \\
\hline
\end{tabular}

a) See Table 2 .

b) Relative concentration of PVY as compared to that in the stem of PVY-infected tobacco. Ten fold (W/ V) diluted suspension of the stem produced about 150 local lesions on a half leaf of C. amaranticolor.

Table 4. Change of CMV concentration in tobacco callus tissue

\begin{tabular}{c|c|c|c|c|c|c|c}
\hline \hline \multirow{2}{*}{$\begin{array}{c}\text { Cultural } \\
\text { condition }\end{array}$} & $\begin{array}{c}\text { Exp. } \\
\text { no. }\end{array}$ & \multicolumn{6}{|c}{ Generation a $^{\text {a }}$} \\
\cline { 3 - 8 } & 1 & $\left.100^{\mathrm{b}}\right)$ & 6 & 1 & 0 & 0 & 0 \\
\hline \multirow{3}{*}{ I } & 2 & 100 & 2 & 0 & 1 & 0 & 0 \\
& 3 & 100 & 2 & 0 & 0 & 0 & 0 \\
\hline \multirow{3}{*}{ IV } & 1 & 100 & 10 & 8 & 1 & 1 & 1 \\
& 2 & 100 & 7 & 9 & 0 & 0 & 0 \\
& 3 & 100 & 4 & 1 & 0 & 0 & 0 \\
\hline
\end{tabular}

a) See Table 2 .

b) Relative concentration of $\mathrm{CMV}$ as compared to that in the tobacco stem originally used for callus establishment. Ten fold (W/V) diluted suspension of the stem produced about 250 local lesions on a half leaf of $V$. sinensis. calli as increase of generations. Under the condition IV, however, the calli became green colored and compact, showing less growth.

As shown in Table 2, PVX concentration in the translucent callus cultured under the condition I abruptly decreased and no longer was detected beyond the 2nd generation while, high PVX concentration was usually maintained under the condition IV.

Change of PVY concentration in tobacco callus tissue

Morphological changes of the calli grown under the conditions in Table 3 were the same as described above.

As shown in Table 3, PVY concentration in translucent and soft callus cultured under the condition I markedly decreased and no virus was detected after the 3rd generation. Whereas, in condition IV, high concentration of PVY was detected in green colored compact callus till the 5th generation.

Change of CMV concentration in tobacco callus tissue

Unlike to the cases of PVX and PVY, CMV activity in tobacco callus diminished under both conditions I and IV during successive generations (Table 4). The rate of decrease was faster in the condition I than in the condition IV, however.

Change of TMV concentration in tomato callus tissue

Since tomato callus did not grow well on the media other than stock medium, tomato callus culture was made by using only stock medium. The translucent and green tissues of a callus was transferred separately to make different lines. Yellowish green and rather compact callus at the 
Table 5. Change of TMV concentration in tomato callus tissue

\begin{tabular}{|c|c|c|c|c|c|}
\hline \multirow{2}{*}{$\begin{array}{l}\text { Cultural } \\
\text { condition }\end{array}$} & \multirow{2}{*}{$\begin{array}{c}\text { Exp. } \\
\text { no. }\end{array}$} & \multicolumn{4}{|c|}{ Generation $^{a)}$} \\
\hline & & 0 & 4 & 8 & 12 \\
\hline \multirow{3}{*}{ II } & 1 & $100^{b)}$ & 0 & 0 & 0 \\
\hline & 2 & 100 & 0 & 0 & 0 \\
\hline & 3 & 100 & 0 & 0 & 0 \\
\hline \multirow{3}{*}{ III } & 1 & 100 & 25 & 26 & 0 \\
\hline & 2 & 100 & 16 & 8 & 0 \\
\hline & 3 & 100 & 30 & 4 & 0 \\
\hline
\end{tabular}

a) See Table 2 .

b) Relative concentration of TMV as compared to that in the stem of TMV-infected tomato. 500 fold (W/V) diluted suspension of the stem produced about 100 local lesions on a half leaf of $N$. glutinosa.

Table 6. Change of PVX concentration in potato callus tissue

\begin{tabular}{c|c|c|c|r|r|r|r}
\hline \hline \multirow{2}{*}{$\begin{array}{c}\text { Cultural } \\
\text { condition }\end{array}$} & $\begin{array}{c}\text { Exp. } \\
\text { no. }\end{array}$ & \multicolumn{6}{|c}{ Generation $^{\text {a) }}$} \\
\cline { 3 - 8 } & 1 & $100^{\mathrm{b}}$ & 176 & 34 & 0 & 0 & 0 \\
\hline \multirow{3}{*}{ II } & 2 & 100 & 215 & 7 & 0 & 0 & 0 \\
& 3 & 100 & 192 & 103 & 121 & 185 & 38 \\
\hline \multirow{3}{*}{ IIIc) $^{c}$} & 1 & 100 & 210 & 127 & 146 & 134 & 109 \\
& 2 & 100 & 276 & 293 & 256 & 359 & 290 \\
& 3 & 100 & 299 & 363 & 344 & 322 & 265 \\
\hline
\end{tabular}

a) See Table 2 .

b) Relative PVX concentration as compared to that in the stem of PVX-infected potato. Ten fold (W/V) diluted suspension of the stem produced about 300 local lesions on 8 half leaves of G. globosa.

c) Brownish compact tissue was used for every transfer. when the tissue grew large enough for use. PVX concentration gradually decreased in translucent tissue, however, it was maintained till the 7 th generation in compact tissue (Table 6).

\section{Discussion}

In this experiment, the morphologically different three viruses, i. e., CMV as a spherical virus, TMV as a rod-shaped virus, and PVX and PVY as filamentous viruses, were employed. The data obtained in this experiment indicated that virus activity in plant callus tissues rapidly decreased under the conditions to produce soft callus without exception and it was usually maintained under the conditions to produce green colored compact callus with some exceptions. On the occasion of tobacco callus tissue infected with PVX, the green colored compact tissue not necessarily maintained the virus (Table 2). CMV in tobacco tissue culture (Table 4) and TMV in tomato tissue culture (Table 5) decreased even under the conditions to produce compact tissue. The authors previously reported $\left.{ }^{9}\right)$ that the rapid decrease of TMV concen- 
tration in friable tobacco callus tissue was considered to be caused by the following reasons; (1) Existence of virus-free cells in some frequencies even in the virus infected tissue. (2) New appearance of virus-free cells from virus infected cells. (3) Virus-free cells grow into clusters escaping from virus infection due to less association of cells and lack of transportation system under the conditions to grow friable callus. (4) The virus-free or diluted clusters thus produced were selected on the occasion of successive transfers.

With regard to the mechanism of the decrease in CMV and TMV concentrations respectively in the compact tobacco tissue and tomato tissue culture, only the second of the foregoing reasons seems to be applicable.

The results obtained in this experiment suggest that it seems possible to eliminate most kinds of virus from the infected tissue cultures by incubating it under the conditions suitable to produce friable callus. Since plantlet was easily differentiated from callus tissue ${ }^{10}$ ), mass production of virus-free plants is conceivably possible from virus-infected plants through callus tissue cultures.

\section{Literature cited}

1) Chandra, $\mathrm{N}$ and Hildebrandt, A. C. (1967). Virology $31: 414-421$.

2) Hansen, A. J. (1974). Ibid. $57: 387-391$.

3) Hansen, A. J. and Hildebrandt, A. C. (1966). Ibid. $28: 15-21$.

4) Hildebrandt, A. C. and Riker, A. J. (1958). Federation Proceedings $17: 986-993$.

5) Kondo, A. (1968). Ann. Phytopath. Soc. Japan $34: 196$ (Abstr.)

6) Mori, K. and Hosokawa, D. (1973). Proc. Kanto-Tosan Plant Protection Soc. $20: 76$. (In Japanese)

7) Murashige, T. and Skoog, F. (1962). Physiol. Plantarum $15: 473-479$.

8) Omura, T. and Wakimoto, S. (1978a) (In press) J. Fac. Agr., Kyushu Univ., 22. 211-219.

9) Omura, T. and Wakimoto, S. (1978b) (In press) Ann, Phytopath, Soc. Japan.

10) Omura, T. and Wakimoto, S. (1978c) (In press) Ann. Phytopath. Soc. Japan.

11) Pillai, S. K. and Hildebrandt, A. C. (1969). Am. J. Bot. $56: 52-58$.

12) Reinert, R. A. (1966). Phytopathology, $56: 731-733$.

13) Svobodova, J. (1966). Viruses of Plants. North-Holland Publishing Co. pp. 48-53.

和 文 摘 要

\section{植物カルス組織からの各種ウイルスの除去}

$$
\text { 大 村 敏 博 } \cdot \text { 脇 本哲 }
$$

ジャガイモ・ウイルスX (PVX)，ジャガイモ・ウイルス Y (PVY) 抽゙キュウリモザイクウイルス（C MV) にそれぞれ䍜病したタバコカルスや，タバコモザイクウイルス（TMV）に瞿病したトマトカルスおよ びPVX に罹病したジャガイモカルスを各罹病植物から起こした。これらのカルスを堅い組織および軟かい 組織が生じやすい適当な条件下でそれぞれ 継代培養してウイルス濃度の消長を検討した結果，すべての宿主 一ウイルスの組み合せにおいて，軟かいカルスを生じる条件下ではウイルス濃度が継代とともに急速に低下 した。堅いカルス中ではウイルス濃度は一般に高いレベルに保たれたが，CMV の場合は堅いカルス中でも 急激に低下し，同様の傾向はトマト組織の TMVでも認められた。 